DIGITALCOMMONS

@WAYNESTATE-
Michigan Journal of Counseling:

Research, Theory and Practice

Volume $31 \mid$ Issue 1

Article 2

$2-1-2003$

\title{
Student Perceptions on the Counselor Education Exit Requirement Experience
}

Toula D. Barlow

Cleveland State University, barlow868@cs.com

Sarah M. Toman

Cleveland State University

Kathryn C. MacCluskie

Cleveland State University

Follow this and additional works at: https://digitalcommons.wayne.edu/mijoc

\section{Recommended Citation}

Barlow, T. D., Toman, S. M., \& MacCluskie, K. C. (2003). Student Perceptions on the Counselor Education Exit Requirement Experience, Dimensions of Counseling, 31(1), 1-8. doi:10.22237/mijoc/1044057660

This Article is brought to you for free and open access by the Open Access Journals at DigitalCommons@WayneState. It has been accepted for inclusion in Michigan Journal of Counseling: Research, Theory and Practice by an authorized editor of DigitalCommons@WayneState. 


\section{Student Perceptions on the Counselor Education Exit Requirement Experience}

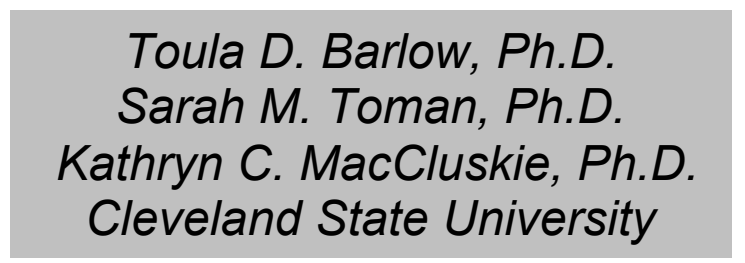

\section{Introduction}

The study of exit requirements is of importance because it provides counselor educators with a final tool for assessing student integration of key concepts and skills commensurate with a graduate degree. As gatekeepers to the profession, we share the responsibility with our new graduates for providing optimal care to clients. Most counseling Master's programs provide means of assessing readiness for the profession, though the method and purpose may vary across programs. Nine studies have been published, to date, (Thomason, Parks, \& Bloom, 1980; Burck \& Peterson, 1983; Kameoka \& Lister, 1991; Peterson, Bowman, Myer, \& Maidl, 1992; Manus, Bowden, \& Dowd, 1992; Dowd, Manus, \& Buboltz, 1995; Loughead, 1997; Carney, Cobia, \& Shannon, 1998; MacCluskie, Toman, \& Barlow, 2000) which consider the method and purpose of exit requirements among graduate programs for mental health professionals. Yet, none of these consider the process and purpose of exit requirements from the perspective of the students themselves. This survey research reports the opinions and experiences of 91 counseling graduates in the context of their involvement with the exit requirement process.
Master's level Counselor Education Programs were asked to participate in a study to determine students' perceptions about the exit requirement experience. Ninety-five recent graduates or graduate students nearing completion of a counselor education degree were surveyed. Results from 91 usable responses indicated that

overall, students who were enrolled in programs that required some form of an exit requirement were satisfied with the process. Furthermore, the majority of these respondents felt that the major purpose of the exit requirement was to measure synthesis of knowledge. Implications for assessment in counselor education programs are discussed. 
A need for consensus has been noted by educators regarding whether comprehensive examinations should demonstrate cumulative knowledge or the ability to apply that knowledge (Thomason, Parks, \& Bloom, 1980). Loughhead (1997) examined rationales for offering Doctoral comprehensive examinations. Peterson, Bowman, Myer, and Maidl (1992) and Manus, Bowden, and Dowd (1992) noted the importance for students of articulating the purpose of exit requirements. Others (Burck \& Peterson, 1983; Dowd, Manus, \& Buboltz, 1995) focused on the psychometric aspects by investigating methods of comprehensive examination administration and scoring. One study examined exit measures from Master's in Social Work programs (Kameoka \& Lister, 1991), while Carney, Cobia, and Shannon (1998) and MacCluskie, Toman, and Barlow (2000) investigated the multiple methods of exiting from Master's level counseling programs.

Given the variety of exit requirement studies from a variety of programs, it is surprising that the student perspective has not previously been reported. Students' perceptions have been considered in regard to a multitude of other training issues. Students have been asked to report about their supervision experiences (Seibold, 1999; Hartung, 1982), their experiences with faculty mentors (Wilde \& Schau, 1991; LeCluyse, Tollefson, \& Borgers, 1985), doctoral training and employment (Auguste, Wicherski, \& Kohout, 1999; Dempster, 1998; Tibbets-Kleber, 1987) and their selfperceptions of future professional role (Delfin \& Roberts, 1980).

In addition, students have been surveyed about the graduate environment's support for professional character and professional values development (Fagan, 1997), research training (Phillips \& Russell, 1994), multicultural training (Constantine, Ladany, Inman, \& Ponterotto, 1996), general training needs (Brown-Wright, Dubick, \& Newman, 1997; Rimmer, Lammert, \& McClain, 1982), and necessary skills (Erffmeyer \& Mendel, 1990; Walfish, Polifka, \& Stenmark, 1984). Texts have been published ( Anderson, 1998; Nerad, June \& Miller, 1997; Delamont, Atkinson, \& Parry, 2000) describing many aspects of the graduate student experience. However, with all these publications, consideration of the students' perceptions of exit requirements from graduate degree programs has not been of primary focus.

To address the aspect of student perceptions, with regard to the exit requirement experience, the researchers of this study surveyed recent graduates or graduate students nearing completion of a graduate degree, from a counselor education program.

\section{Method}

\section{Participants}

Ninety-one students who were nearing graduation or who had recently graduated from a Master's counseling degree program participated in the study. The process of obtaining participants was two-fold. First, a letter was sent to the 391 counselor education programs located in the United States and listed in Counselor Preparation (Hollis and Wantz, 1993). Each program chair was asked for help in recruiting students to complete a survey. Eighty-one program chairs agreed to provide access to their recent upcoming graduates. Some programs preferred to distribute the surveys to their students, while other chairs provided students' names and addresses to the investigators. Of the 81 potential respondent programs, 31 (38\%) actually provided access to the students. From the 31 programs, the investigators obtained 319 potential individual student/graduate respondents. 
The second phase was completed by providing explanation letters and surveys to the 319 individual students. In the cases where chairs did not disclose students' names to the researchers, the chairs agreed to be responsible for distributing the letters and instruments to potential respondents. Two forms of the survey were used: Form I for students graduating from a program which administered an exit requirement, and Form II for students graduating from a program which did not have the requirement. The surveys were returned to the investigators with an enclosed, stamped envelope.

\section{Instrumentation}

The surveys were designed for this study by the investigators. The researchers returned to the original instrument used in MacCluskie, Toman, and Barlow (2000), the literature, and informal feedback from advisees, to construct the demographic form and survey items. Form I contained 10 quantitative items (3 demographic questions and 7 items), and two qualitative questions. Questions inquired about (a) respondent demographics; (b) type of exit requirement; (c) respondent's status of pass/fail; (d) respondent's experience with the process and perceptions for the rationale of the exit requirement; and (e) two open-ended questions. Form II consisted of two quantitative items and one qualitative question. Questions here included: (a) respondent demographics; (b) respondent's perceptions of the degree completion process and whether an exit requirement was viewed as valuable; and (c) an open-ended item inviting respondent's opinions concerning how the experience could have been improved.

\section{Results}

Of the 319 individual students, a total of ninety-five $(30 \%)$ completed and returned the surveys. Four surveys were not usable due to the respondents' incorrect completion of the survey or because respondents were a doctoral student instead of a Master's student. Of the remaining surveys, 73 were from students in programs requiring some form of exit requirement (Form I), while 18 did not have an exit requirement (Form II). The geographic distribution of the student participants are included in Table 1.

Twenty- four states were represented, with the greatest $\%$ of responses coming from the states of New York and Louisiana.

Table 1: Geographic Distribution of Respondents in Counselor Education

\begin{tabular}{|l|c|c|c|c|}
\hline & \multicolumn{2}{|c|}{$\begin{array}{c}\text { Respondents of } \\
\text { Exit } \\
\text { Requirements }\end{array}$} & \multicolumn{2}{c|}{$\begin{array}{c}\text { Respondents of } \\
\text { No Exit } \\
\text { Requirements }\end{array}$} \\
\hline State & $\mathrm{n}$ & $\%$ & $\mathrm{n}$ & $\%$ \\
\hline Alabama & 1 & 1.4 & - & - \\
\hline Florida & 4 & 5.5 & - & - \\
\hline Illinois & 5 & 6.8 & - & - \\
\hline Indiana & 2 & 2.7 & - & - \\
\hline lowa & 3 & 4.1 & - & - \\
\hline Louisiana & 13 & 17.8 & - & - \\
\hline Maryland & 2 & 2.7 & - & - \\
\hline Michigan & 1 & 1.4 & - & - \\
\hline Minnesota & 4 & 5.5 & - & - \\
\hline Mississippi & 1 & 1.4 & - & - \\
\hline Nebraska & 2 & 2.7 & - & - \\
\hline Nevada & 1 & 1.4 & - & - \\
\hline New Jersey & 2 & 2.7 & - & - \\
\hline New York & 5 & 6.8 & 11 & 61.1 \\
\hline North Dakota & 1 & 1.4 & - & - \\
\hline Ohio & 2 & 2.7 & - & - \\
\hline Pennsylvania & 1 & 1.4 & 4 & 22.2 \\
\hline South & 1 & 1.4 & - & - \\
\hline Carolina & & & & - \\
\hline Tennessee & 1 & 1.4 & - & - \\
\hline Texas & 5 & 6.8 & - & - \\
\hline Virginia & 3 & 4.1 & 3 & 16.7 \\
\hline Washington & 4 & 5.5 & - & - \\
\hline West Virginia & 5 & 6.8 & - & - \\
\hline Wisconsin & 4 & 5.5 & - & - \\
\hline Total & 73 & 100.0 & 18 & 100.0 \\
\hline & & & & \\
\hline
\end{tabular}


The distribution of training tracks for exit and non-exit requirements students are included in Table 2 . The majority of students who responded to this question indicated that they were enrolled in Community/Agency counseling programs. This was consistent across both survey instruments, $42.5 \%$ for Survey Form I, and $61.1 \%$ for Survey Form II.

The remaining results of the responses to Forms I and II will be discussed separately, since they were sampling two different populations of respondents, and due to the fact that the remaining items differed significantly between the two survey forms. Results obtained from Form I will be discussed first, followed by the results of Form II.

Section III of Survey Form I contained seven items, in a Likert-type format. Results of each item will be discussed separately because the anchors on the Likert scales varied with each survey item.

Item 1 represents the degree to which exit requirement preparation could help students in their future employment. These results indicate that the majority of the students $(82.2 \%)$ who answered this item felt that exit requirements were to some degree beneficial to their role as future clinicians. Item 2 represents the estimation of helpfulness of the exit requirement process in integrating a sense of the "big picture" in the field of professional counseling. A total of $77 \%$ of the respondents who answered this question found exit requirements to be at least moderately beneficial.

The next survey item, Item 3, inquired as to the accuracy with which exit requirements reflected curriculum material. The highest frequency of responses (93\%) occurred in the range between 3 and 5, suggesting these students perceived their exit requirements to be adequately sampling the curriculum content. Item 4 asked whether respondents believed exit requirements were a good idea. The majority of the responses $(92 \%)$ were favorable. It appears that students generally felt exit requirements to be a good idea.

Table 2: Distribution of Students in Various Specialty Tracks

\begin{tabular}{|l|c|c|c|c|}
\hline & \multicolumn{2}{|c|}{$\begin{array}{c}\text { Exit } \\
\text { Requirement } \\
\text { Track }\end{array}$} & \multicolumn{2}{c|}{$\begin{array}{c}\text { No Exit } \\
\text { Requirement } \\
\text { Track }\end{array}$} \\
\hline $\begin{array}{l}\text { Master's } \\
\text { Program of } \\
\text { Study }\end{array}$ & $\mathrm{n}$ & $\%$ & $\mathrm{n}$ & $\%$ \\
\hline $\begin{array}{l}\text { School } \\
\text { Counseling }\end{array}$ & 5 & 6.8 & 4 & 22.2 \\
\hline $\begin{array}{l}\text { Community/ } \\
\text { Agency }\end{array}$ & 31 & 42.5 & 11 & 61.1 \\
\hline $\begin{array}{l}\text { Marriage and } \\
\text { Family }\end{array}$ & 5 & 6.8 & - & - \\
\hline $\begin{array}{l}\text { Student } \\
\text { Personnel }\end{array}$ & 12 & 16.4 & - & - \\
\hline Rehabilitation & 3 & 4.1 & 3 & 16.7 \\
\hline $\begin{array}{l}\text { Counseling } \\
\text { Psychology }\end{array}$ & 9 & 12.3 & - & - \\
\hline $\begin{array}{l}\text { Educational } \\
\text { Guidance }\end{array}$ & 5 & 6.8 & - & - \\
\hline Other & 3 & 4.1 & - & - \\
\hline
\end{tabular}

Item 5 pertained to level of satisfaction with the format of the exit requirement. $87 \%$ of the responses were positive. Again, students seemed satisfied to some degree with the format of their exit requirement. Item 6 measured the degree of satisfaction with the helpfulness of faculty in preparing students for the exit requirements. $81 \%$ of those responding to this particular item found faculty to be helpful to some degree.

Satisfaction with the overall exit requirement process was the last of the Likert-format questions. Eighty-three \% of those responding to this item reported being somewhat satisfied, to completely satisfied with the overall exit requirement process.

Question eight on Survey Form I, dealt with the perceived emphasis placed on the rationale for utilizing exit requirements. Respondents were asked to rate various items based on the degree of emphasis each item possessed (a great deal of emphasis, moderate emphasis, and little emphasis). Results are presented in Table 3. Overall, it 
appears that students perceived the primary emphasis to be integration of knowledge. Seventy-four $\%$ of respondents felt that a great deal of emphasis was placed on integration of knowledge.

\section{Qualitative Questions Survey Form I}

To the open item, question nine, ("Please describe any alternatives or changes you would recommend to improve your current exit requirement format or procedure") 56 students $(77 \%)$ responded. Ten students indicated that no changes were necessary, while 41 students offered one or more procedural recommendations or recommendations for the faculty. The alternate procedures recommendations included doing a research project $(\mathrm{n}=1)$, case studies $(n=2)$, group therapy $(n=1), a$ portfolio $(n=2)$, more writing $(n=1)$, oral exams $(\mathrm{n}=1)$, or addressing individualized learning needs $(n=1)$. As well, there were four students who noted that passed state board licensure exams could suffice for an exit requirement. The largest procedural recommendation, though, was nine calls for a method of assessing counseling skills.

There were also 27 recommendations to the faculty. These included more focused questions $(\mathrm{n}=3)$, consistent scheduling $(\mathrm{n}=2)$, consistency in grading $(\mathrm{n}=2)$, and not giving out questions ahead of time $(n=1)$. Many students perceived that exit requirements should be more meaningful to the counseling profession $(n=6)$, should better reflect course content $(n=6)$, that preparation needed more faculty involvement $(\mathrm{n}=2)$, with some specifying that faculty offer outlines or summaries $(n=2)$ seminars $(n=1)$, sample questions $(n=1)$, or a list of resources, $(n=1)$. Five comments were not usable because they made program recommendations instead of exit requirement recommendations.

For question ten ("Use the space below for additional comments about your exit requirement experience"), 14 students reported a variety of experiences in completing exiting requirements, 5 negative aspects and 9 positive aspects.

Table 3: Perceived Emphasis Placed on Rationale for Utilizing Exit Requirements

\begin{tabular}{|l|c|c|c|c|}
\hline & \multicolumn{3}{|c|}{ Extent of Emphasis } & \\
\cline { 2 - 5 } & Heavy & Moderate & Minimal & Other \\
\hline $\begin{array}{l}\text { Perceived } \\
\text { purpose }\end{array}$ & $\%$ & $\%$ & $\%$ & $\%$ \\
\hline $\begin{array}{l}\text { Screening for } \\
\text { minimal } \\
\text { knowledge }\end{array}$ & 46.5 & 43.7 & 9.9 & - \\
\hline $\begin{array}{l}\text { Screening for } \\
\text { minimal skill }\end{array}$ & 34.3 & 40.0 & 25.7 & - \\
\hline $\begin{array}{l}\text { Integration of } \\
\text { knowledge }\end{array}$ & 74.3 & 18.6 & 7.1 & - \\
\hline $\begin{array}{l}\text { Professional } \\
\text { writing or } \\
\text { presenting } \\
\text { skills }\end{array}$ & 32.9 & 44.3 & 21.4 & 1.4 \\
\hline $\begin{array}{l}\text { Learning } \\
\text { experience }\end{array}$ & 44.3 & 41.4 & 12.9 & 1.4 \\
\hline $\begin{array}{l}\text { Evaluation of } \\
\text { program }\end{array}$ & 15.0 & 42.3 & 42.3 & - \\
\hline $\begin{array}{l}\text { Evaluation of } \\
\text { faculty }\end{array}$ & 14.0 & 36.8 & 49.1 & - \\
\hline Other & 33.3 & - & - & 66.7 \\
\hline
\end{tabular}

For example, one student indicated it resembled a "frat hazing," and another wrote "it was a complete waste of time," while others wrote that "it brought the profession of counseling together for me," and "helped clarify future goals." Six additional students referred to assistance from faculty in regard to their exit experience as positive $(n=2)$, no help $(\mathrm{n}=2)$, and that faculty's own issues got in the way of evaluating students $(n=1)$. One student reported that passing classes was the "real preparation". Two respondents indicated that they passed their state license exam and another wished they had chosen one of the other exit requirement options. Five comments were not usable because they made program comments instead of exit requirement comments. 


\section{Survey Form II}

Survey Form II was utilized by those students who did not have an exit requirement as part of their counseling program. There were two quantitative questions in Survey Form II and the results of these two questions are highlighted in Table 4 . The first quantitative question dealt with whether some form of an exit requirement would have been helpful in consolidating knowledge of the counseling coursework. Approximately $28 \%$ of the respondents indicated that they would not find an exit requirement at all helpful in consolidating knowledge, while 50\% reported that that an exit requirement may have been helpful to some degree. It is important to note that of those surveyed, no one responded that an exit requirement would have been extremely helpful.

The second quantitative question assessed whether an exit requirement would have been helpful in students' future roles as clinicians. $28 \%$ of those who responded to this item reported that an exit requirement would not have been helpful, while approximately $38 \%$ felt that an exit requirement would have been helpful to some degree. Once again, no one responded that an exit requirement would have been extremely helpful in their future role as clinicians.

\section{Qualitative Question Survey Form II}

As part of the qualitative component of this research, the last item of Survey Form II pertained to whether the respondents would have liked some form of closure to their educational experience. The dichotomous scale of "yes" or "no," was also supplemented with a section where respondents could provide further details about their answer. 11 students from the 18 surveys returned, made one or more responses stating "Yes," with indications of those experiences being a practical project $(\mathrm{n}=3)$, seminar with peers and professionals $(n=3)$, exit interview with advisor $(n=2)$, assessment of practical applications $(n=1)$, and portfolio $(n=1)$, "No," their experience was "sufficient," or that they were assessed prior to internship

Table 4: Student Perceptions of Effectiveness of Exit Requirements: Non-Exit Requirement Track

\begin{tabular}{|c|c|c|c|c|c|c|c|c|c|c|}
\hline \multirow{3}{*}{$\begin{array}{l}\mathrm{l} \\
\mathrm{t} \\
\mathrm{e} \\
\mathrm{m}\end{array}$} & \multicolumn{10}{|c|}{ Likert Ratings } \\
\hline & \multicolumn{2}{|c|}{$\begin{array}{c}1 \\
\text { Not at } \\
\text { all } \\
\text { helpful }\end{array}$} & \multicolumn{2}{|c|}{2} & \multicolumn{2}{|c|}{$\begin{array}{c}3 \\
\text { Some } \\
\text { what } \\
\text { helpful }\end{array}$} & \multicolumn{2}{|r|}{4} & \multicolumn{2}{|c|}{$\begin{array}{c}5 \\
\text { Extre- } \\
\text { mely } \\
\text { helpful }\end{array}$} \\
\hline & $\underline{\mathrm{n}}$ & $\%$ & $\underline{\mathrm{n}}$ & $\%$ & $\underline{\mathrm{n}}$ & $\%$ & $\underline{\mathrm{n}}$ & $\%$ & $\underline{\mathrm{n}}$ & $\%$ \\
\hline 1 & 5 & 27.8 & 4 & 22.2 & 5 & 27.8 & 4 & 22.2 & - & - \\
\hline 2 & 5 & 27.8 & 6 & 33.3 & 5 & 27.8 & 2 & 11.1 & - & - \\
\hline
\end{tabular}

\section{Discussion}

The purpose of this study was to further investigate whether exit requirement processes were beneficial from the students' views, and whether student perceptions of the intent for exit requirements are congruent with those of faculty, which was measured in a previous study (MacCluskie, Toman, \& Barlow, 2000). The findings were encouraging. First, and perhaps most importantly, the majority of student respondents did feel that the process was beneficial for them on a number of levels. It helped students get a sense of the big picture in the field. Sometimes it might be difficult for students, particularly those taking one or two courses at a time, to sense a comprehensive conceptualization for the overall field of counseling, within their particular discipline. Studying for an exit examination, which often entails amassing syllabi over the course of the curriculum, and studying course material in the context of other course material, does seem to be one effective means for helping the students 
consolidate and integrate a broad range of information.

Also of importance, the prior survey by MacCluskie, Toman, \& Barlow, (2000) found that the most common intention of faculty, in using the exit requirement procedure, was integration and synthesis of knowledge. Student perceptions were found to be congruent with faculty intent. This could mean that faculty are adequately communicating their intent. Furthermore, students completing exit requirements found the process to sample the curriculum content.

The question arises whether there are areas in which faculty might improve the exit requirement process. On the survey items, a preponderance of respondents answered favorably. Perhaps faculty could refine their approaches to assisting students with the exit requirement preparation process. There may be great variability between programs, or even between advisors/faculty members within a program, as to the extent to which they offer assistance to students in this regard. Nevertheless, $79 \%$ of students found their faculty members to be helpful to some degree with exit requirement preparation, while more ( 83 percent) were to some degree satisfied with the overall exit requirement process.

One finding that does not necessarily indicate need for improvement, but does need to be acknowledged, is that both faculty and students saw assessment of applied clinical skills as a much lesser goal, in comparison to assessment of knowledge. Where are applied clinical skills being assessed in a curriculum? They may be assessed in a piecemeal fashion across courses, but most likely it occurs primarily in internship. In some programs, instructors of internships are faculty supervisors, but the site supervisors are the individuals who have the most responsibility for monitoring students' clinical skills. This raises two important points. First, faculty need to make sure they trust the skill level of the site supervisors. Second, clinical site supervisors are assigned a great deal of responsibility for final assessment of students' skills.

To summarize, students enrolled in programs utilizing exit requirements saw the primary purpose as intended to measure integration of knowledge. These results are consistent with faculty members' intentions. Overall, students involved in the exit requirement process had positive perceptions of the process. If alternate exit requirement procedures are implemented, further research will be needed to assess faculty and student perceptions of the process and content. One emerging trend seems to be portfolio development. Future research should continue to assess the efficacy of new exit requirement procedures with student perceptions and assessments.

\section{References}

Anderson, M. S. (1998). The experience of being in graduate school: An exploration. San Francisco: Jossey-Bass Publishers.

Auguste, R. M., Wicherski M., \& Kohout, J. L. (1999). 1996 master's specialist's and related degrees employment survey. APA Research Office Technical Reports. American Psychological Association Research Office, US.

Brown-Wright, D. A., Dubick, R. A., \& Newman, I. (1997). Graduate assistant expectation and faculty perception: Implications for mentoring and training. Journal of College Student Development. 38(4), 410-416.

Burck, H. D., \& Peterson, G. W. (1983). Doctoral comprehensive examinations in one program. A descriptive and evaluative study. Counselor Education and Supervision, 23, 169-172.

Carney, J.S., Cobia, D.C., \& Shannon, D.M. (1998). An examination of final evaluation methods used in master's level counseling programs. Counselor Education and Supervision, 37, 154165.

Constantine, M. G., Ladany, N., Inman, A. G., \& Ponterotto, J. G. (1996). Students' perceptions of multicultural training in counseling 
psychology programs. Journal of Multicultural Counseling and Development, 24, 241-253.

Delamont, S., Atkinson, P., \& Parry, O. (2000). The doctoral experience: Success and failure in graduate school. New York: Falmer Press.

Delfin, P. E. \& Roberts, M. C. (1980). Selfperceived confidence and competence as a function of training in the beginning graduate student in clinical psychology. Teaching of Psychology, $i$, 168-171.

Dempster, L. V. (1998). A descriptive study of community mental health professionals regarding their graduate training and specific professional functions. Dissertation Abstracts International, 49 (4-A) 729-730.

Descutner C. J., \& Thelen, M. H. (1989). Graduate student and faculty perspectives about graduate school. Teaching of Psychology, 16, 58-61.

Dowd, E. T., Manus, M. B., \& Buboltz, W. C. (1995). The comprehensive examination in professional psychology. Paper presented at the Greater Lakes Regional Conference in Counseling Psychology, Kent, Ohio, MarchApril, 1995.

Erffmeyer, E. S., \& Mendel, R. M. (1990). Master's level training in industrial/organizational psychology: A case study of the perceived relevance of graduate training. Professional Psychology: Research \& Practice, 21, 405-408.

Fagan, A. F. C. (1997). The development of professional character: An investigation of the values of graduate students in counseling psychology. Dissertation Abstracts International: Section B: The Sciences \& Engineering, 57(7-B), 4704.

Hartung, B. J. (1982). The practicum instructor: A study of role expectations. Journal of Sociology \& Social Welfare, 9, 662-670.

Hollis, J. A., \& Wantz, R. A. (1993). Counselor preparation 1993-1995 Volume 1: Programs and personnel (8th Ed.). Bristol, PA: Accredited Development.

Kameoka, V. A. \& Lister, L. (1991). Evaluation of student learning outcomes in MSW programs. Journal of Social Work Education, 27, 251-257.

LeCluyse, E. E., Tollefson, N., \& Borgers, S. B. (1985). Differences in female graduate students in relation to mentoring. College Student Journal, 19, 411-415.

Loughhead, T.O. (1997). The doctoral comprehensive examination: Fine-tuning the process. Counselor Education and Supervision, 37, 140-148.

MacCluskie, K. C., Toman, S. M., and Barlow, T. D. (2000). A national survey of exit requirements among master's in counseling programs. Dimensions of Counseling, 28, 18-24.

Manus, M. B., Bowden, M. G., \& Dowd, E. T. (1992). The purpose, philosophy, content, and structure of doctoral comprehensive/qualifying exams: A survey of counseling a psychology training programs. The Counseling Psychologist, 20, 677-688.

Nerad, M., June, R., \& Miller, D.S. (Eds.) (1997). Contemporary higher education: International issues for the twenty-first century. New York: Garland Publishing, Inc.

Peterson, S. E., Bowman, R. L., Myer, R. A., \& Maidl, C. M. (1992). A survey of comprehensive examination practices among doctoral programs in counseling. Counselor Education and Supervision, 32, 117-129.

Phillips, J. C., Russell, R. K. (1994). Research selfefficacy, the research training environment, and research productivity among graduate students in counseling psychology. Counseling Psychology, $22,628-641$.

Pilkington, N. W., \& Cantor, J. M. (1996). Perceptions of heterosexual bias in professional psychology programs: A survey of graduate students. Professional Psychology: Research and Practice, 27, 604-612.

Rimmer, S. M., Lammert, M., \& McClain, P. (1982). An assessment of graduate student needs. College Student Journal, 16, 187-192.

Seibold, J. M. (1999). The experiences of master's level marriage and family therapy students in their off-campus placements. Dissertation Abstracts International: Section B: The Sciences \& Engineering, 59, (11-B) 6078.

Tibbets-Kleber, A. L. (1987). Doctoral training in clinical psychology: The student's perspective. Dissertation Abstracts International, 47(8-B), 3548.

Thomason, T. C., Parks, J. C., \& Bloom, J. W. (1980). The doctoral comprehensive examination in counselor education. Counselor Education and Supervision, 19, 182-185.

Walfish, S., Polifka, J. A., \& Stenmark, D. E. (1984). An evaluation of skill acquisition in community psychology training. American Journal of Community Psychology, 12, 165-174.

Wilde, J. B., \& Schau, C. G. (1991). Mentoring in graduate schools of education: Mentees' perceptions. Journal of Experimental Education, $59,165-179$. 